ppi $201502 Z U 4645$

Esta publicación científica en formato digital es continuidad de la revista impresa ISSN-Versión Impresa 0798-1406 / ISSN-Versión on line 2542-3185Depósito legal pp $197402 Z$ U34

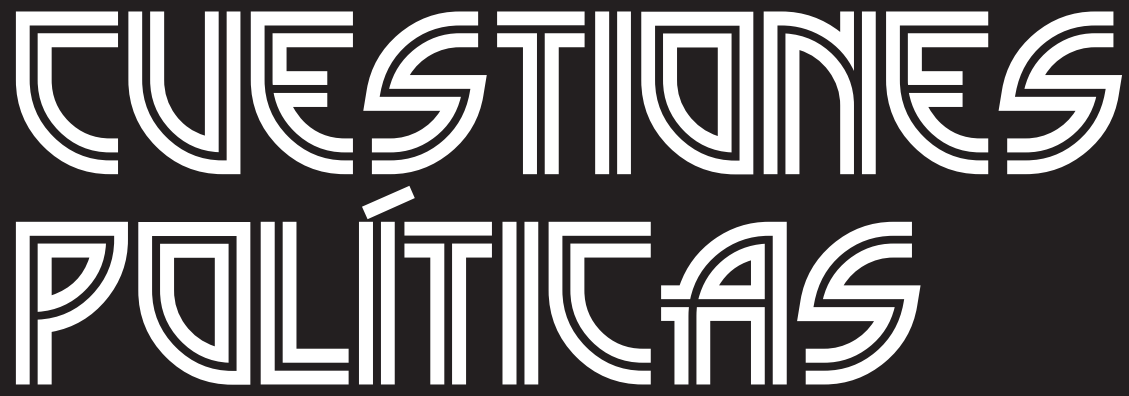

Instituto de Estudios Políticos y Derecho Público "Dr. Humberto J. La Roche" de la Facultad de Ciencias Jurídicas y Políticas de la Universidad del Zulia Maracaibo, Venezuela
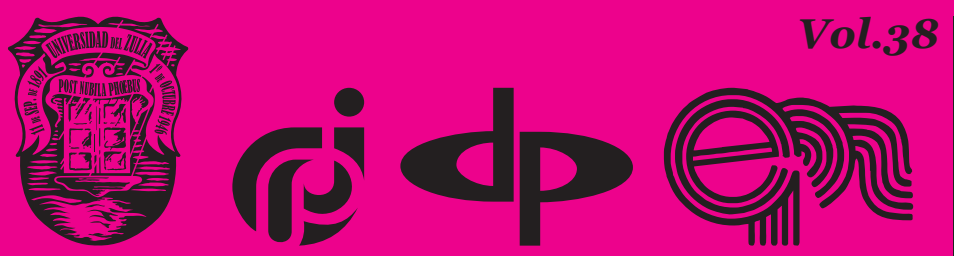

$N^{\circ}$ Especial 1era Parte 2020 


\title{
Ethnopolitics: regulatory principles of ethno-separatism
}

\author{
DOI: https://doi.org/10.46398/cuestpol.38e.14
}

\section{Imdad Bayramov *}

\begin{abstract}
The existing relationship, both in theory and in concrete historical reality, between economics, political development and ethnicity is substantial, to the point that ethno-politics can then be talked about as a novel field of study that, although based on political science, quickly transcends the order of the multi and interdisciplinary. It is order of ideas; this research article was aimed at identifying from the perspective of ethno-political analysis the principles that regulate the discourse of ethnoseparatism. At the methodological level, documentary research technique was used. It is concluded that ethnicity goes through certain stages in its historical development. Political records show. the existence of a multidimensional ethos that is observed culturally, socially, and democratically as a material and symbolic force that identifies some communities while differentiating them from others. Ethno-politics is in fact part of the concept of a political nation that preserves ethno-socialsofactors. From that moment on, the category of ethno begins to subsumme the historical memory of the community and the national thought that determines its level of modern consciousness.
\end{abstract}

Keywords: ethno-politics; ethno-separatism; economic development; critical historical period; nation-building.

\footnotetext{
*Associate Professor of Baku State University, Azerbaijan. ORCID ID: https://orcid.org/oooo-ooo28892-8713. Email: Imdad_bayramov@list.ru
} 


\section{Etnopolítica: principios reguladores del etno- separatismo}

\section{Resumen}

La relación existente, tanto en la teoría como en la realidad histórica concreta, entre economía, desarrollo político y etnicidad es sustancial, hasta el punto de que se puede hablar entonces de la etno-política como un novedoso campo de estudio que, aunque tiene su base en la ciencia política, trasciende rápidamente al orden de lo multi e interdisciplinar. Es orden de ideas, el presente artículo de investigación se planteó por objetivo identificar desde la perspectiva de análisis etno-política los principios que regulan el discurso del etno-separatismo. En el plano de lo metodológico se hizo uso de la técnica de investigación documental. Se concluye que la etnicidad pasa por ciertas etapas en su desarrollo histórico. Los anales políticos evidencian, la existencia de un ethos multidimensional que se observa en lo cultural, social y democrático como fuerza material y simbólica que identifica a unas comunidades al tiempo que las diferencia de otras. La etno-política parte en efecto del concepto de una nación política que preserva factores etno-sociales. A partir de ese momento, la categoría de etno comienza a subsumir la memoria histórica de la comunidad y el pensamiento nacional que determina su nivel de conciencia moderna.

Palabras clave: etno-política; etno-separatismo; desarrollo económico; período histórico crítico; construcción de la nación.

\section{Introduction}

Today the political composition of many countries of the world, the state of socio-economic inequality and differences in political positions, the development of high-level technologies that regulate public consciousness, the presence of self-determination in international law. As a result of ethno-separatism in our time, several countries were divided (SSRI, Czechoslovakia, Yugoslavia) and new ones were created. Potentially, differences based on the subconscious we-they dichotomy are historical in terms of formation.

For example, there are many historical reasons for the national-ethnic separatist movement that has gradually intensified in the post-Soviet space since the 1970 s and 1980 s. Because the post-council $\mathrm{m} \square$ kanında yasayan various halqların religious, cultural, national, etc. "Halqlar dostlugu" based on the principle of class identity unifikasiya at the national level ziyalı class hostility damgası under represiyalara have been subjected to 
natural heritage surviving rights have been questioned private property. As a result of the weak national policy of political leadership, many peoples were displaced within the country, and the policy of poor governance within the country led to the deterioration of interethnic relations. The linguistic, religious and national mentality of the peoples living in the Soviet Union, the world's largest region in terms of ethnic diversity, was so diverse and varied that even a Western researcher is still a researcher.

Today we have shown our influence on the formation of national and ethnic conflicts in Karabakh, South Ossetia, Abkhazia, Transnistria and in many Balkan countries, which are partly under the socialist regime. Sociopsychological factors that were suppressed only by fear of the collapse of totalitarian systems have shifted from psychological to physical to take advantage of existing historical conditions. We do not want to associate the roots of these psychological factors with a specific historical period. Because, according to C. Jung's theory, the origin of the "we-they" dichotomy comes from the collective subconscious level that goes back to mythical times. A practice that unites three main factors based on: firstly, the centrist who headed the Chiharan's national identity is the existence of certain political forces with a radical mood.

In the USSR, the use of the term "Soviet people" for all peoples was a means of covering up ethnic conflicts. The Soviet period, material and cultural values, which yaratdıgı cohusu "sinfilik" have a threat of destruction under the name of the very Hirdagerak recession, is also a place for the ethnoslar than other raziy stories of exile, national survivors and new "Soviet insans". Under Stalin, there were no serious ethnic protests the totalitarian regime and the Second World War, which intensified every year. During the war, the solidarity of the Soviet people and the general feeling of their homeland increased significantly.

Oriented to the method of socialism-realism, the creative people of that period believed that there was no ethnic difference at all and that a great ethnonym called the "Soviet nation" was gradually forming. However, one of the main factors accelerating the process of interethnic instability in the USSR was the incorrect regulation of national policy. Instead of ensuring the interests of peoples in a fair and democratic manner, without affecting national interests and national identity, the state does not use the power of an authoritarian regime to ensure the interests of peoples. Without the use of methods in accordance with the rules of the civilized world, democratic principles such as referendums, polls, opinion polls, any nation, ethnic minority constitute a minority. Thus, the use of administrative and bureaucratic methods has created conditions for the further exacerbation of national problems (Korolev, 1970). 


\section{Soviet Period}

In the USSR, nationalism has always developed in secret. The poll results showed that Russians (68\%) had more place in the USSR than other countries. Studies have shown that in the 1970 s and 1980 os, the participation of non-Russians in the party ranks significantly decreased compared to the 1920s. V. Tishkov, Analysis of the published biographies of 193 members and candidates for members of the Politburo (Presidium), Organizational Bureau and Secretariat of the Central Committee of the Communist Party for 1919-1990. The fact that Russians are the majority in the USSR proves that non-Russians were discriminated against, and not, as they say, SovietRussian nationalism. The views expressed by British anthropologist Ernest Gellner in Nation and Nationalism may be useful in proving that the collapse of the USSR was driven in part by national issues and the rise of nationalism.

According to Gelner, nationalism is, first of all, a political principle that requires the coincidence of political and national-cultural values. Violation of this principle, the absence of political and state institutions that ensure the development of the nation and its culture, leads to the emergence of nationalist sentiments and mass protests. Conflicts are inevitable where such violations exist. According to Gelner, nationalism is not unique to a backward society; nationalism is created in times of high literacy, the creation of mass media and communication, and the creation of national intellectual elites. If a society is ready for nationalism in the era of industrialization, its development cannot be prevented.

National awakening occurs when the masses feel that there is a discrepancy between what is possible and the state of their national cultures, that their national cultures are not protected politically by the authorities. At this stage, nationalism becomes aggressive. It should be noted that Soviet society was also going through a period of active industrialization; the level of literacy and national elites was high. National cultures needed or depended on the help of state institutions (Tishkov, 1997; Gelner, 2003).

With the emergence of the problem of Nagorno-Karabakh, the process of the collapse of the USSR accelerated. This conflict also led to the emergence or re-emergence of national-political conflicts in the Union, especially in the Caucasus. The struggle of Armenians against aggressive separatism and terrorism radically changed the ethnic situation in the USSR, proving once again that the Soviet leadership is not capable of solving national problems. Armenian aggressors living inside and outside the Nagorno-Karabakh conflict, their organizations, the patronage of Armenians by the Soviet leadership, and so on. The struggle of the Armenians continued intensively both abroad and within the Union. 


\author{
Imdad Bayramov \\ 212 \\ Ethnopolitics - the principles of regulation of ethno-separatism
}

Since the composition of most states in the modern world is multiethnic, the policy of any modern nation state is the basis of any modern nation state, regardless of the form of government, territorial structure, regime, as well as socio-political, cultural and economic development. For this purpose, the concept of strategy, approach, principles and goals of the implementation of complex measures related to the establishment of interethnic relations, the scientific catalog "Ethnopolitics".

Ethnic politics is an internal affair of every state. However, when any state cannot regulate its internal situation in the context of globalization and integration, it has the right to intervene in solving an international problem. Because many countries try to solve the problem by violating human rights and using violence. This creates conditions for internal dissatisfaction, destabilization, escalation of the political crisis and, finally, the outbreak of armed clashes. In our time, more attention is paid to the analysis of ethno-separatism from a modernist point of view. In these concepts, ethnoseparatism arises as a result of the provocation of small ethnic groups of large states to a standardized way of life (westernization) and their fear of losing their identity and national culture. It is this psychological state that gradually begins to develop as follows:

1. Activation of the historical memory of the ethnos by humanitarian intellectuals in a social group and the actualization of ethnic identity on it.

2. Formation of a political party based on the institutionalization of the movement

3. Mobilization of party activities to expand the social base of separatism

4. Transformation of separatist demands into an emotional and psychological state.

\title{
2. Ethnic policy
}

Ethnic policy should be based on a concept consisting of concrete and practical measures. In this concept, it is necessary to regulate relations between ethnic groups in the country in all three spheres of public life (administrative-political, socio-cultural and economic). Ethnic policy of any civilized democratic country should be aimed at solving the following problems:

- The position of ethnic groups in the state or in a specific region that is a national minority.

- The position of compatriots abroad. 
- Illegal migration (voluntary and forced).

- Demographic situation (proportionality and locality).

- Ethnocultural enclaves and diasporas.

- Ethnic problems in state and local structures.

- Ethnic problems in the education system.

- Settlement of ethnic conflicts.

- National unity.

International organizations (Council of Europe, UN) have adopted a number of documents with international status to regulate interethnic relations. At present, international standards of ethno-state policy of the state are based on two contradictory categories related to the selfdetermination of peoples and the rights of minorities (national, ethnic, cultural, religious and linguistic). Because here the content of the concept "people" and its connection with the concept of "nation" lead to different interpretations. Traditionally, the concept of "people" includes all people in a particular country, their common language, history, psychological state and cultural traditions. Ethnos and nation also have different meanings, as we have already mentioned. Within the state, these elements can manifest themselves in one way or another. Ethnopolitics should consist of public policies that shape the relationship and unity between these elements. However, self-determination often comes into conflict with the interests of the state. Ethnicity based on rational principles should serve to regulate these conflicting and dynamic interests in a unified system. Self-regulation can have different characteristics due to its dynamic nature. They can be partially characterized as follows:

- Anti-colonial self-determination (a certain population trying to get rid of the colony or gain more political power).

- Self-determination from the "state" or on the territory of the state (separation from one state and the creation of another state or obtaining high political and cultural autonomy in this state).

- Transnational self-government (the requirement to unite the population on a large territory of the state territory);

- Self-determination among widespread peoples (the requirement of peoples living in one state or in many states).

- Self-determination of indigenous peoples (a requirement of a local social group with a long history of pre-ethnic identity and colonialism).

- Self-representation (demand of the population to see their representatives in the government to change their political system). 


\section{Imdad Bayramov \\ 214 \\ Ethnopolitics - the principles of regulation of ethno-separatism}

The concept of ethnos, defined as a historical and social category, is broader, more complex and older than the concept of nation and people. The phenomena of people and a nation are, in fact, different historical forms of an ethnos. In the regulation of civil-human relations at the national level, the protection of the rights of ethnic minorities in an ethnos, which is quantitative (if the ethnic composition of the population is different) (if it is the majority in the state), deserves special attention. Because, unlike the ethnic level, the concept of a nation is a form of social cohesion that ensures political cohesion. However, this political unity contains elements of the phenomenon of ethnos. In this sense, the origin of the problem of separatism in any case intersects with ethno-separatism. Therefore, the study of separatism requires a certain clarity on the phenomenon of ethnicity.

Since the genesis and development of an ethnos is regulated both by the biological laws of nature and by social laws that are in dialectical unity with them, synchrony is syncretic in solving the problem. The Marxist literary ethnos is defined within a more socio-historical class category. The boundaries of the ethnic group do not coincide with this. Due to natural differences, he has his own chronological socio-economic education. Separatism differs from the national liberation movement in that it has a number of specific features and in many cases serves the interests of national minorities.

Nationalism emerges as a developed form of ethnic evolution. In terms of the mechanisms of influence on the civil-human factor, it manifests itself in the forms of polyethnic and monotheistic nationalism. Multiethnic nationalism is also called civic nationalism. Civil nationalism, besides any ethnic nationalism, determines the dynamics of national solidarity and regulates ethnic stability in multinational countries. At the same time, the most important positive principle is the principle of not transforming civil nationalism into state nationalism. But monotheistic nationalism removes the fear that nationalism will become a dangerous factor like state nationalism (for example, as in Japan).

In the process of creating a doctrine about ethnicity, it is necessary to pay attention to the acceptable generally accepted meanings and criteria that the phenomenon of "national minority" carries. More than 20\% of the world's population belongs to the category of "national minorities". Their existence does not depend on the decisions of the state. The development of civil society does not harm their existence. In addition, each person must decide if everyone belongs to this social category. In terms of their legal requirements, these groups can be divided into two categories:

1. Members of a social group in a minority are generally equal to the dominant group that rejects discrimination. 
2. Members of a minority social group should have special rights in addition to the same rights as the dominant group, which rejects discrimination against the dominant group. use their language orally or in writing in the legislature, in the administration, in the courts and in public relations in general.

An analysis of international documents regulates the attitude of an ethnic group towards national minorities as follows (Saveliev, 1990):

- Each member of the group should be given the opportunity to use their cultural values, to perform their religious rites in accordance with their religion and to speak fluently in their native language.

- Forced learning should not be allowed.

- Discrimination should be prohibited and everyone should be equal before the law.

- Terrorism and extremism should not be identified with any religion, culture, ethnic group or nation.

- It is necessary to provide support and development of the institution of national-cultural autonomy.

- A sense of tolerance and cultural pluralism needs to be developed through education.

- The language of the national minority should be used in educational and administrative bodies and taught in the field of education. Their development in the field of national television, radio and press should be regulated by the state.

- Going to court in their native language, economic activity must be ensured.

- Historical place names must be recognized.

Along with the state language, their language should be protected and should not be attacked by the language of the" titular nation ".

- Consultations with national-cultural autonomies and organizations of national minorities should be held.

- Their political interests, human rights must be protected, and their participation in public life must be ensured.

In all cases, the state is responsible for regulating ethno-separatism. Researcher V.A. Avksentyev, who has long been engaged in research in this area. For a successful solution of the problem, the following was proposed (Gumilov, 1996). 


\author{
Imdad Bayramov \\ 216 \\ Ethnopolitics - the principles of regulation of ethno-separatism
}

1. This is not about eliminating separatism, but about its localization, that is, about providing it with a limited political and ideological "shelter" outside the political "center".

2. The state will seriously respond to the appeal of the ethnic group regarding its dissatisfaction and the beginning of an urgent constructive dialogue and, if possible, refrain from it.

3. It is necessary to try to solve the problem on the spot on the spot, so as not to become a stereotype of thinking.

4. The state must take certain measures at the international level to eliminate internal and external factors that contribute to the growth of separatism.

\title{
3. Manifestations of ethno-separatism
}

The problem of ethno-separatism was presented in various forms within the framework of certain historical ideological systems and has become an object of scientific research in our time. In Soviet times, the emphasis on class relations and the study of politics as the main subject, as well as the surveillance of national movements, led to the fact that the problem of ethno-separatism was paid little attention. Socio-psychological problem of the twentieth century as a psychological and social problem, telling about etnik qurumlarm, life operations "partlayss" and a brief history of world communities, which are small states representing separate states that are currently located in different states, in contrast to many other countries that currently belong to different state borders in different countries of the world.

Was connected. It would be wrong to associate the reasons for this only with certain historical conditions and the level of socio-economic development, with differences in socio-cultural development and the system of relations. Since the root of the problem is mainly associated with the peculiarities of the psychological state of the ethnic group, the psychological characteristics of the national character, separatism as an ethnopsychological phenomenon must be studied both from a theoretical and practical point of view.

Many complex ethnopsychological phenomena, whose separatist genesis, structural and functional reviews first study individual national characteristics, psychological characteristics, various ethnopsychological stereotypes, various views and traditions, as well as various social theories, various social theories, it is important to pay attention to this. We are primarily interested in the phenomenon of ethnos, which is the most 
primitive and complex form of social unity. Because this phenomenon, as a complex socio-psychological phenomenon, manifests itself in all forms of historical social unity in one or another manifestation of separatism.

Of course, ethnic attitudes that reflect an effective component of ethnic identity play a certain role in the emergence of ethno-separatist tendencies. His welcoming member of the Ethnic Association Olmakdan Pleasure, his request for grant and his culture, ozun $\square \mathrm{m} \square$ hsuslugunun, traditions passed down by edilm $\square$ sin дости, reach the initiative, give self-confidence to increase halqlarm ozunut $\square$ yinetm $\square$ si Rights have proclaimed that this negative and important role is also important, that rights, like many others, are as important as others. of course, if this right does not materialize under certain conditions). Psychological determinants expressed during the indifference of the ruling ethnic groups to the national feelings of minorities in this country can act as explosives in other ethnoseparatist processes.

In interethnic relations, the need for the subject's awareness of legal consciousness occupies a special place in the structure of his needs. Thus, a person who is a bearer of ethnic self-awareness, proceeding from the provision of his social needs, the position of belonging to an ethnic group, takes place in the structure of ethnic needs, where his needs are assessed. The contradiction between the indicators of the vital activity of an ethnic group and its level of socially significant needs and the level of objective possibilities of their existence in the specific historical conditions of a particular existing country is contradictory. With the correct organization of the policy of ethnic relations, the discrepancy between these two events can turn from a negative factor into a source of reducing social tension in the ethnic environment (Posh, 1995).

It is well known that the resolution of social conflicts is the source of the development of social systems, including ethnic institutions. Or other interests of the group as a result of qrulararası konfliktin uyusmayan ortaya crhan separatizm MSerif puts forward the following hypothesis regarding the interdependence of the two groups: direct hostility in the spirit of functionality leads to a form of competition, negative stereotypical attitudes and social social groups, as well as to social groups and public figures , as well as to public and social groups, as well as to social groups and public figures, as well as to public and social groups, as well as to social groups and public figures, as well as to public and social groups, as well as to social groups and public figures, as well as public and social groups, as well as social groups and public figures, as well as public figures, as well as public and social groups, as well as public groups and public figures, as well as public organizations, and to public education.

And two phenomena (ethnic conflict and ethno-separatism) merge into one phenomenon. Referring to their judgments and conclusions, we 
can conclude that there is a danger of ethnic conflict, which is expressed in the form of aggressive hostility in interethnic interactions. Interethnic interactions do not always and do not necessarily reflect real conflicts. Public-historical experience shows that this is quite enough, since there may be cases when an elder gives an ethnic conflict zahiri, a distorted character in a bear, or, conversely, in accordance with interests, as is usually the case, even if it is not is a prerequisite for comparison.

In conditions when the traditions of statehood were not very ancient, such an ethnos-psyche arose from the deepest layers of mythological thinking. According to L. Gumilyov, the ethnos should form in a short time as a closed system that strives for independence and isolation. Ethnicity creates urgent social institutions for self-defense. However, to determine the phase of ethnogenesis, it is necessary to know the main parameters of the studied period. The main parameters are behavioral imperatives (requirements) associated with spatial awareness and the logic of events. This is due to the movement of the ethnosystem.

Speaking about passion, L. Gumilev had in mind the excess of biochemical energy in living beings, as well as in the person to whom they belong. Each ethnic system was a small type of superethnoses that represent several ethnic groups - subethnoslars embrace and lure in any kind of biological and energetic aspects, such as "views", "some of which may be even lower", which may even lead to that some of them might even downgrade, which might cause some of them might even cause a little bit of this feeling, which might even cause some of them might even cause a little bit of this a feeling that it could lead some of them to even get a little carried away, which could even lead to some of them being so low that they could even lead to such a low that they could lead to such a low that could lead to such a low level that it could lead to such a low level that it could lead some of them to even understand get carried away a little, which may even cause some of them to even get a little carried away, which can lead to a level so low that it can lead to a level so low. associated with the rise.

According to him, the processes of ethnogenesis are the result of "explosions" or "upheavals" that lead to the emergence of new ethnic systems in a particular region. Thus, in subethnos, the resistance of the ethnic system to fragmentation is disturbed by an increase in attraction - energy that can satisfy the need for self-affirmation. The supernatural seeks to expand its territory and complicate inter-ethnic relations. The forces of his development are "taken from passion" (Tokarev, 1986). The resistance of the subsystems and their attempt to separate them leads to the disintegration of the supernatural into a number of independent ethnosystems. Any polyethnos is unstable in space and time, and its existence as a system is conditioned by the resistance factors of subethnos and their attempts to live freely and independently. The struggle of these 
different polar forces is eternal and indestructible. In addition to the commendable views of L.N. Gumilyov, his views on the process of ethnoseparatism in connection with the analogy between social and physical, biological and chemical processes. That is, this concept does not take into account the specificity of development forms, their inseparability from each other.

Ethnic communities have their own ethnopsychological characteristics. They become the main socio-psychological factor that determines the characteristics of ethnic separatism, which manifests itself in various forms. Some studies in the field of ethnopsychology, based on confirmed results, prompts you to separate the tolerance of khalkald, twazokarlyk, respect for elders and other similar key factors, ambition, pride, resentment, Kisaslyg courts, the charge of giving law and order, Ethno-psychological processes throughout the post-Soviet space arise under the influence of ethnopsychological phenomena. This is even more evident in the attempts of peoples to achieve psychological independence and separatism in solving economic, political and social problems in various ethnic regions.

Ethnic behavior stereotypes change both in space and in time. Any voluntary or involuntary human action occurs in one way or another under any influence. There is no doubt that under the influence of informal ethnic assessment, a mental trait such as anger is formed in people. This tendency is closely related to the separatist function of ethnic consciousness. Many psychological characteristics of an ethnos under the influence of imperatives (unconditional requirements) formed in connection with the established criterion for assessing the mental image of an ethnos are separatist actions. From this point of view, cultural separatism, due to its ethnopsychological characteristics, is more fundamental than its other forms. Because ethnopsychological characteristics are traditionally transmitted in cultural culture through cultural heritage and genetic characteristics. The phenomenon of culture determines the contours of ethnic self-awareness and forms the basis of irrational behavior.

This is manifested mainly in the language factor. The characteristic features of traditional culture and everyday life determine the general ethnic image of the phenomenon of the people, which is characterized as a socio-cultural concept. Culture is also a material and spiritual value that has historically been shaped as the common wealth of various ethnic groups. In multinational countries, the carriers of these resources are the multiethnic majority. At some points in its history, ECO, which has been subject to different cultural influences, coexists with others, integrating similar functions. S.A. Tokorev identified four basic psychological types of ethnos in four formations: tribal-consanguinity of the collective; demos active, free people, not counting slaves; On the eve of populist feudalism, the entire able-bodied population of the country entered it; excluding religious class; national capitalism, a product of the socialist era (Talha et al, 2020). 


\author{
Imdad Bayramov \\ 220 \\ Ethnopolitics - the principles of regulation of ethno-separatism
}

In general, not only ideas change and acquire a new essence, but also the psyche. It is with the renewal of the psyche that the four ethnic differences mentioned by S.A.Tokorev arise. The characteristics of communities, more or less differing from each other in language, traditions, ideology, are determined by their historical purpose and ethnic groups as a system of historical processes. It is wrong to associate this with the name of an ethnic group. This is due to the fact that an ethnos that has gone through the stages of development, "maturity" and "aging" in its development, is established at the stage of maturity, and at the same time its periphery is formed. The main process of renewal takes place within the ECO, the periphery becomes more inert and archaic.

This reflects the huge role of socio-political (former state) structures in the socio-economic and cultural development of ethnic groups. During the transition period and in extreme conditions, events occur that give rise to the development of separatism, that is, society is completely politicized, the old idea collapses, and the new one is accepted in society. When both the real historical reality and the features of the historical past contradict consciousness, the desire of society to think of a new type arises - a new form of worldview. The fact that a person wants and demands that something is not real requires changes in ideological consciousness, in contrast to ordinary consciousness. Before the collapse of the Soviet empire, a new philosophical worldview of changes was formed in Azerbaijan. As the desire to change the forms of social and political life grew, this worldview began to influence the ordinary level of consciousness.

\title{
Conclusions
}

Ethnicity goes through certain stages of its historical development. Political annals back, in a cultural, social, democratic, unifying ethnos, as well as in the world community and powers between the independence of enlightenment, economic sovereignty, national heritage, voluntariness, reciprocity and reciprocity of all levels of volunteers. It is part of the concept of a political nation that preserves ethnosocial factors while providing other means. From that moment on, the concept of ethnos begins to become the historical memory of the community that it expresses, and national thinking determines its level of modern consciousness. However, ethnic origin retains its potential at a subconscious level.

If one or another social process within the existing boundaries of an ethnic group is destructive, then this leads to a deformation of this social process and a certain potential form of tension in the ethnic environment. This can develop into social and psychological conflicts in this and other spheres of ethnic life, if the situation is not corrected in time. In this regard, 
people need spiritual closeness from the point of view of ethnic kinship, and they feel the need to understand the specifics of the reflection of objective reality and its contradictions in ethnic consciousness. We are talking about all the contradictory manifestations that make up the "dialectic of the soul" - habits, characters, ways of thinking of individuals as representatives of ethnic unity. With this approach to the problem, it is possible to find out the driving forces and sources of ethnic separatism in the social context.

\section{Bibliographical References}

GELNER, Elena, 2003. Nacii'ta nacionalizm; Nacionalizm (Nations and Nationalism; Nationalism)'. Per. z angl. G. Kas' janov. (In Checo).

GUMILOV, Lev I. 1996, Ethnogenesis and the biosphere of the earth. Russian Peoples' Friendship University. Moscow, Russia.

KOROLEV, Sergey.I, 1970. Issues of ethnopsychology in the works of foreign authors. Russian Peoples' Friendship University. Moscow, Russia.

POSH, Bin, 1995. "Crisis of the territorial state: separatism and federalism in Europe in the 1990s. (on the example of Belgium and Italy)" In: Ethnicity National movements. Social practice. SPb. No, 14, pp. 118-140.

SAVELIEV, Andrey, 1990. Sovereignty, federalism, separatism. Available online. In: http://www.netda.ru. Consultation date: 12/03/2019.

TALHA, Muhammad: Dr SANA, Azeem: MISHEL, Sohail: ALMAS, Javed: RABIA, Tariq 2020. "Mediating effects of reflexivity of top management team between team processes and decision performance" In: Azerbaijan Journal of Educational Studies. Vol. 690, No. 1, pp.112-129.

TISHKOV,Valery, 1997. "Ethnicity, nationalism and conflict in and after the Soviet Union" In: The mind aflame. Vol. 15, No, 5, pp. 335-359.

TOKAREV, Sergei A. 1986. The chosen ones. The writing. Moscow, Russia. 


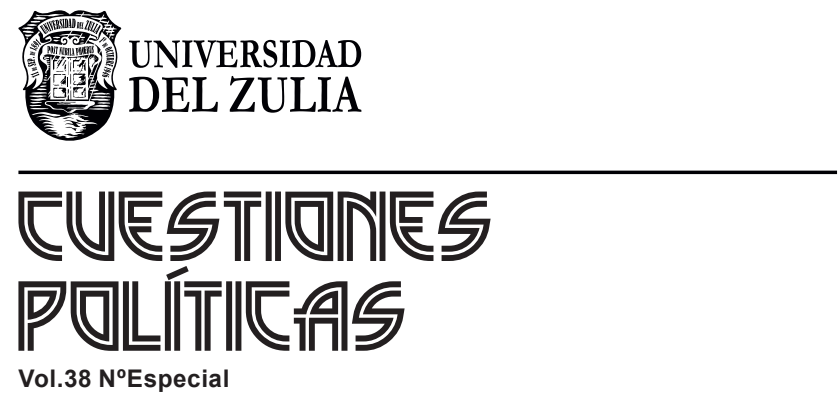

www.luz.edu.ve 